\title{
Antibacterial activity of Calendula officinalis and Echinacea purpurea extracts against the causal agent of tomatoes' bacterial canker: Clavibacter michiganensis subsp. michiganensis
}

[Actividad antibacteriana de los extractos de Calendula officinalis y Echinacea purpurea contra el agente causal del cancro bacteriano del tomate: Clavibacter michiganensis subsp. Michiganensis]

Hasan Murat Aksoy ${ }^{1}$, Şahane Funda Arslanoğlu ${ }^{2}$, Mohamed Faraj Edbeib ${ }^{1,3}$, Yilmaz Kaya ${ }^{4,5}$ \& Sevgi Marakli ${ }^{6}$

\author{
${ }^{1}$ Plant Protection Department, Agriculture Faculty, Ondokuz Mayis University, Samsun, Turkey \\ ${ }^{2}$ Department of Field Crops, Faculty of Agriculture, Ondokuz Mayis University, Samsun, Turkey \\ ${ }^{3}$ Department of Medical Laboratories, Faculty of Medical Technology, Baniwalid University, Libya \\ ${ }^{4}$ Department of Agricultural Biotechnology, Faculty of Agriculture, Ondokuz Mayis University, Turkey \\ ${ }^{5}$ Department of Biology, Faculty of Science, Kyrgyz-Turkish Manas University, Bishkek, Kyrgyzstan \\ ${ }^{6}$ Department of Medical Services and Techniques, Sabuncuoglu Serefeddin Health Services Vocational School, Amasya, Turkey
}

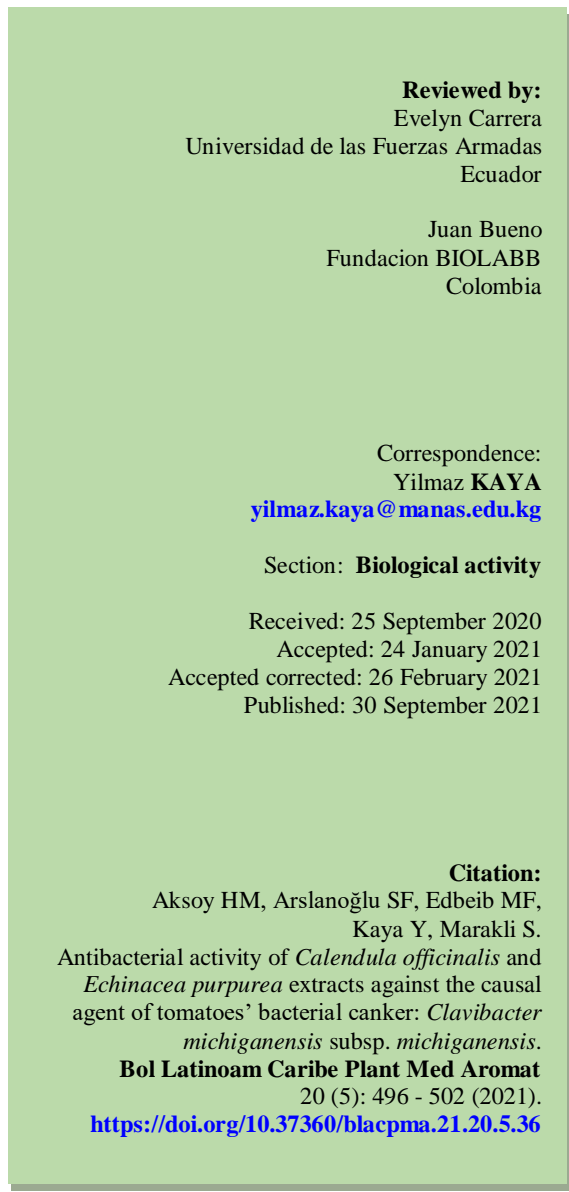

Abstract: We aimed to investigate the effects of Calendula officinalis and Echinacea purpurea extracts in terms of growth parameters, antibacterial activity and phenolic profile in tomato infected by Clavibacter michiganensis subsp. michiganensis $(\mathrm{CmmT7})$. A significant difference was observed in $E$. purpura extract, indicating the highest effects on plant height $(27.25 \mathrm{~cm})$, fresh plant weight $(28.45 \mathrm{~cm})$, root length $(24.42 \mathrm{~cm})$, and root weight $(6.74 \mathrm{~g})(p<0.05)$. Moreover, Calendula officinalis and Echinacea purpurea extracts showed significant inhibitory activity against CmmT7 $(p<0.05)$. Among phenolic compounds, the only chlorogenic acid amounts were varied in the tomato seedlings leaves with $C$. officinalis extract $(\mathrm{K} 3)+C m m \mathrm{~T} 7$, E. purpurea extract $(\mathrm{E} 3)+C m m \mathrm{~T} 7$ and CmmT7 $(p<0.01)$. Moreover, chlorogenic acid amount was approximately 9 times higher than in CmmT7-treated leaves when compared to control. The results showed that application of the extracts of these plants had a significant influence on bacterial canker and growth parameters.

Keywords: Leaf extract; Plant pathogenic bacterium; Plant bioactive compounds; Medicinal plants; Tomato

Resumen: Nuestro objetivo fue investigar los efectos de los extractos de Calendula officinalis y Echinacea purpurea en términos de parámetros de crecimiento, actividad antibacteriana y perfil fenólico en tomate infectado por Clavibacter michiganensis subsp. michiganensis (CmmT7). Se observó una diferencia significativa en el extracto de E. purpura, que indica los mayores efectos sobre la altura de la planta $(27,25 \mathrm{~cm})$, el peso de la planta fresca $(28,45 \mathrm{~cm})$, la longitud de la raíz $(24,42 \mathrm{~cm})$ y el peso de la raíz $(6,74 \mathrm{~g})(p<0,05)$. Además, los extractos de Calendula officinalis y Echinacea purpurea mostraron una actividad inhibidora significativa contra CmmT7 $(p<0,05)$. Entre los compuestos fenólicos, las únicas cantidades de ácido clorogénico se variaron en las hojas de las plántulas de tomate con extracto de $C$. officinalis (K3) Cmm T7, extracto de E. purpurea (E3) CmmT7 y CmmT7 ( $p<0.01$ ). Además, la cantidad de ácido clorogénico fue aproximadamente 9 veces mayor que en las hojas tratadas con CmmT7 en comparación con el control. Los resultados mostraron que la aplicación de los extractos de estas plantas tuvo una influencia significativa sobre el cancro bacteriano y los parámetros de crecimiento.

Palabras clave: Extracto de hoja; Bacteria fitopatógena; Compuestos bioactivos vegetales; Plantas medicinales; Tomate 


\section{INTRODUCTION}

Clavibacter michiganensis subsp. michiganensis is a Gram-positive bacterium, causing bacterial canker on Solanum lycopersicum and also huge financial losses in marketable tomato production zones (Gleason et al., 1993; Moustaine et al., 2019). Bacteria pass through a natural opening such as stoma before they move into the xylem (Gartemann et al., 2003; Ansar et al., 2019). As a result of stunting and wilting, crop quality and loss may occur in plant and "bird's eye" on the fruit (Utkhede and Koch, 2004; Osdaghi et al., 2020). The solution of the tomato bacterial canker disease is based on the rotation of the crop, clean transportation practices, and even the usage of healthy seeds (Tireng Karut et al., 2019). In addition to these natural solutions, chemical pesticides have been applied but the disease has still been appeared and also caused several symptoms on plants. Therefore, the prevention of bacterial disease by applying chemical pesticides are restricted or prohibited in many countries (Valdés et al., 2017). For this reason, biological control as natural methods has been commonly used for plant protection. In these methods, naturally extracted substances obtained from plants are commonly used as a biological control against plant pathogens (Valdés et al., 2017; Bahaman et al., 2020).

C. officinalis L. (Asteraceae) has been one the best known traditional medicinal plants with stimulant and antispasmodic properties since ancient times (Latifian et al., 2018). The plants are used in folk medicine of different part of world, especially Europe. The plant contains different phenolic compounds including quinones, volatile oil, carotenoids, triterpenoids, flavonoids, coumarins etc. (Muley et al., 2009). C. officinalis was chosen for its properties to inhibit different anaerobic and facultative aerobic periodontal bacteria including Porphyromonas gingivalis, Prevotella spp., Furobacterium nucleatum, Caphocytophaga gingivalis, Veilonella parvula, Eikenella corrodens, Peptostreptococcus micros and Actinomyces odontolyticus (Lauk et al., 2003; Khare 2004; BenErik and Michael, 2004; Gazim et al., 2008). Furthermore, C. officinalis extracts indicated anticancer effects in vitro studies on tumor cell lines (Jimenez-Medina et al., 2006). Another plant used in this study, Echinacea purpurea L., has been widely used to alleviate colds, rethroats and other upper respiratory infections. This plant consists of caffeic acid derivatives, alkamides, polysaccharides and glycoproteins. Especially caffeic acid derivatives possess many bioactive functions such as antioxidant, antidiabetic, antihyaluronidase, antiviral activities (Chiou et al., 2017).

In this study, phenolic profile of $C$. officinalis and E. purpurea was analysed. Moreover, antibacterial effects and also phenolic profiles of $C$. officinalis and $E$. purpurea extracts in tomato seedlings infected by $C$. michiganensis subsp. michiganensis ( $\mathrm{CmmT7}$ ) were also investigated by using disc diffusion method and HPLC, respectively in addition to growth parameters.

\section{MATERIALS AND METHODS}

\section{Plant material and preparation of extracts}

C. officinalis and E. purpurea were collected from Field Crops Department's experimental area of Agricultural Faculty of Ondokuz Mayis University, Samsun, Turkey. The harvested samples were transferred in the clean plastic bags and numbered. For one week, the plants were air-dried in darkness followed by drying in an oven at $35^{\circ} \mathrm{C}$ for 24 hours. The plant leaves were pulverized and $2 \mathrm{ml}$ methanol $(80 \%, \mathrm{v} / \mathrm{v})$ was added to $200 \mathrm{mg}$ plant powder for methanolic extraction. Then, samples were incubated with shaking overnight. The extracts were obtained by centrifuging at $10000 \times g$ for $30 \mathrm{~min}$. The supernatants were collected and kept at $4^{\circ} \mathrm{C}$ until use.

\section{Disc diffusion test}

Antibacterial effects of plant extracts on $\mathrm{CmmT7}$ were evaluated by Kirby-Bauer disc diffusion method (Tortora et al., 2001). The bacterial isolate, CmmT7, was provided by Ondokuz Mayis University, Agricultural Faculty, Plant Protection Department, Bacteriology Lab. (Samsun, Turkey). The bacterial isolate was incubated for $24-48 \mathrm{~h}$ at $26^{\circ} \mathrm{C}$ on Nutrient Agar-NA (Difco). Then, the turbidity of the suspension was adjusted to an optical density at 600 $\mathrm{nm}\left(\mathrm{OD}_{600}\right)$ of $0.7\left(\sim 1 \times 10^{8} \mathrm{CFU} / \mathrm{mL}\right)$. Samples from $100 \mu \mathrm{l}$ of the inoculum media were added on NA plaques under aseptic conditions and spread using sterilized cotton swabs. Filter paper discs (Oxoid) soaked with $15 \mu \mathrm{l}$ of each plant aqueous extract $(1 \mathrm{~g} / \mathrm{ml})$ were placed on NA in Petri dishes, incubating at $26^{\circ} \mathrm{C}$ for $24-48 \mathrm{~h}$. The inhibition zone was measured in diameters using a stereomicroscope (Olympus SZ-61). The experiment was repeated three times.

\section{Effect of the plant extracts and CmmT7 on plant growth}

4-week-old tomato seedling cv. H 2274 was used for the determination of antibacterial effects of $C$. officinalis and E. purpurea. The concentration of 
bacteria suspensions was $10^{8} \mathrm{CFU} / \mathrm{ml}$ and the plant extracts were $20 \mathrm{~g} / \mathrm{l}$. Both bacteria and extracts were applied to tomato plants for one week. There were six treatments: (i) tomato seedlings with $C$. officinalis extract (K3)+CmmT7, (ii) tomato seedlings with $E$. purpurea extract (E3)+Cmm $\mathrm{T} 7$, (iii) tomato seedlings with $C$. officinalis extract (K3), (iv) tomato seedlings with E. purpurea extract (E3), (v) tomato seedlings + CmmT7, (vi) tomato seedlings with deionized sterile water (control). Only plant extract applications (iii iv) were as follows: lateral roots of 4 weeks-old tomato seedlings were pruned with a scalpel and soaked in $50 \mathrm{ml}$ of the extracts of $C$. officinalis and $E$. purpurea for $2 \mathrm{~h}$ at room temperature. Then, $\mathrm{Cmm \textrm {T } 7}$ was inoculated onto the same tomato seedlings by the cotyledon clipping method for i-ii applications. Moreover, CmmT7 isolate was inoculated to the 4week-old tomato plantlet for the treatment $\mathrm{v}$ by using the cotyledon clipping method (Xu et al., 2010). Cotyledons of tomato plantlets were obtained using deionized sterile water method for the control treatment (vi). After applications, tomato plantlets were planted into $250 \mathrm{ml}$ pots including a soil mixture $(1: 1$ soil:sand, w/w). The samples were then transferred in sterilised plastic saucers on greenhouse benches to prevent contamination. The pots were randomly placed in growing chambers at $24^{\circ} \mathrm{C}, 16 / 8$ day/night conditions and $70 \%$ relative humidity. Experiments were repeated three times for each bacterial strain and plant extract combinations. Plant heights, fresh plant weights, root lengths and root weights were analysed in addition to phenolic compounds.

\section{Extraction of phenolic compounds}

Tomato seedling leaves were analysed for the determination of phenolic compounds. Samples were quickly transferred into a liquid nitrogen tank to avoid spoilage and stored at $-80^{\circ} \mathrm{C}$. Then the phenolic compounds were identified by HPLC analysis. The standard technique was performed with minor modifications (Yang et al., 2015). Every single sample (1 g) was mixed with $20 \mathrm{ml}$ of $80 \%$ methanol-water mixture $(\mathrm{v} / \mathrm{v})$ used as an extraction liquid and vortexed for $10 \mathrm{~min}$. Afterwards, the solutions of extracts were transferred for $1 \mathrm{~h}$ at $50^{\circ} \mathrm{C}$. After centrifugation at $12.000 \mathrm{rpm}$ at $4^{\circ} \mathrm{C}$ for $10 \mathrm{~min}$, the supernatants were filtered through PTFE hydrophilic syringe filter $(0.45 \mu \mathrm{m}$ pore size, $13 \mathrm{~mm}$ diameter). Dried samples were resuspended in 1.0 $\mathrm{mL}$ HPLC grade methanol by vortexing and stored at $4^{\circ} \mathrm{C}$ for further analysis.

\section{Statistical analyses}

Kolmogorov-Smirnov One Sample test results presented that all traits could be assumed normally distributed $(p<0.05)$. Levene variance homogeneity test results showed that all traits had homoscedasticity $(p<0.05)$. Then, One-Way ANOVA test was performed on all data, Duncan's multiple range test was performed to compare the means. Moreover, relations among traits were also investigated by using Pearson Correlation analyses with SPSS 20.0 program.

\section{RESULTS AND DISCUSSION}

\section{Disc diffusion test}

The inhibitory values (mm) of $C$. officinalis and $E$. purpurea extracts against $C m m \mathrm{~T} 7$ were indicated in Table No. 1. C. officinalis and E. purpurea extracts showed significant similar inhibitory activity against CmmT7.

Table No. 1

Antibacterial activity of $C$. officinalis and $E$. purpurea

\begin{tabular}{lc}
\hline \multirow{2}{*}{ Treatments } & Cmm T7 \\
\cline { 2 - 2 } Control & Mean diameter zone of inhibition $(\mathbf{m m}) *($ Mean \pm SE) \\
\hline C. officinalis $(\mathrm{K} 3)$ & $0.0 \pm 0.0 \mathbf{b}$ \\
\hline E. purpurea $(\mathrm{E} 3)$ & $42.0 \pm 1.76 \mathbf{a}$ \\
\hline
\end{tabular}


Effect of the plant extracts and CmmT7 on plant growth

Tomato seedlings were treated with $C$. officinalis, $E$. purpurea extracts alone and also in combination with CmmT7 in addition to deionized sterile water (control), showing similar effects on all plant growth parameters including root weights, root length, plant height and fresh plant weight (Figure No. 1).
Moreover, a significant difference was also recorded between plant extracts - treated tomato seedlings and other treatments $(\mathrm{K} 3+C m m \mathrm{~T} 7, \mathrm{E} 3+C m m \mathrm{~T} 7$, and Cmm 77) $(p<0.05)$. Among the treatments, extract of E3 showed the highest effects on plant height (27.25 $\mathrm{cm})$, fresh plant weight $(28.45 \mathrm{~g})$, root length (24.42 $\mathrm{cm})$, and root weight $(6.74 \mathrm{~g})(p<0.05)$ (Figure No. $1)$.

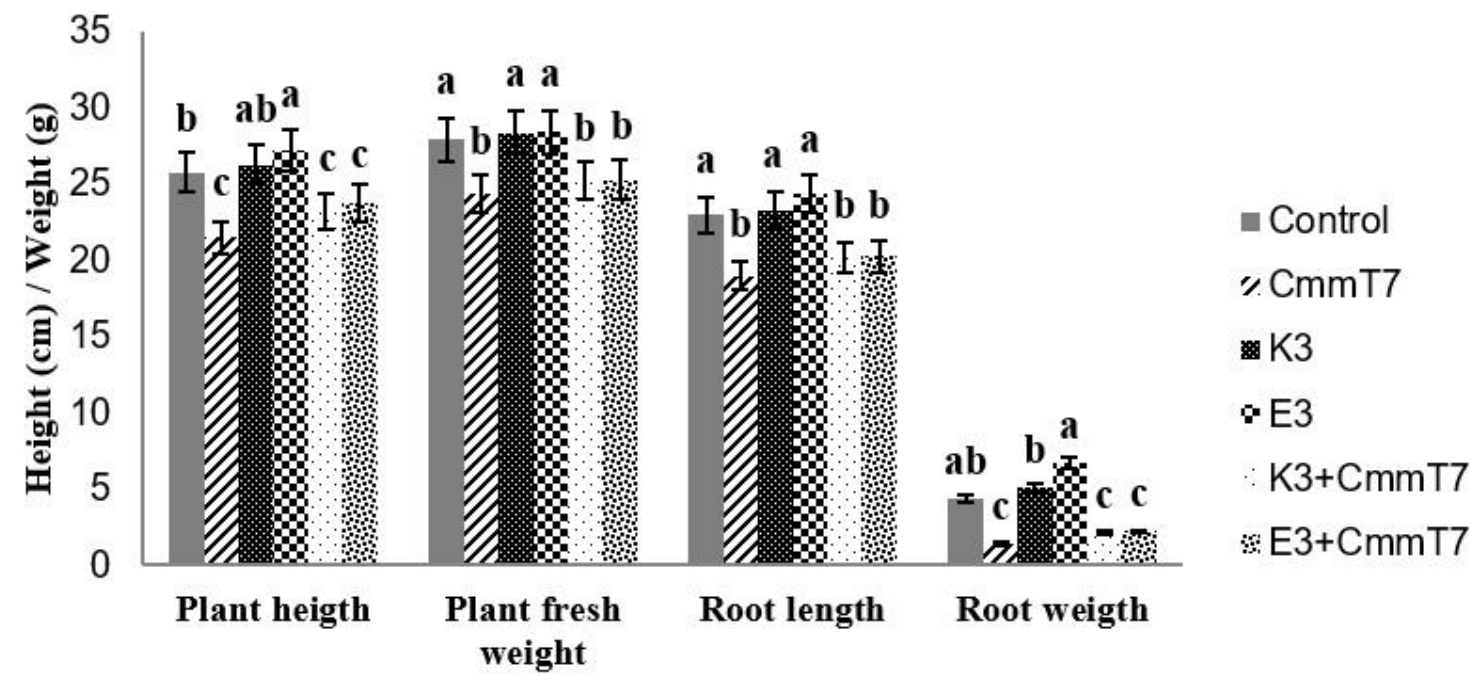

\section{Treatments}

Figure No. 1

The antibacterial effects of $C$. officinalis and $E$. purpurea alone and in combination with $C m m \mathbf{T}$ on growth of tomato (The values are expressed in mean \pm standard deviation. Different letters above the bars are significant at $p<0.05$ as a result of Duncan's Multiple Range Test).

\section{Phenolic contents}

Phenolic compounds consisting of vanillic acids, tannic, catechin, rosmarinic, rutin, salicylic, caffeic, cinnamic, ferulic, gallic and oxalic were detected in trace amounts in all treatments $(<0.01,<0.025,<0.01$, $<0.01,<0.04,<0.01,<0.05,<0.01,<0.05,<0.01$ and $<0.01 \mu \mathrm{g} / 100 \mathrm{~g}$ dry weight, DW). Only one phenolic compound, chlorogenic acid was significantly presented. The accumulation of chlorogenic acid $(8.90 \mu \mathrm{g} / 100 \mathrm{~g} \mathrm{DW})$ was measured as the highest amount in leaves with treated $\mathrm{Cmm}$ T7, indicating 9 times higher than control plants. In addition, K3 + $\mathrm{CmmT7}$ and E3 + CmmT7 - treated leaves, were significantly higher than $\mathrm{KE}$ and $\mathrm{E} 3$ extracts and even control (Figure No. 2).

In this study, both in vivo and in vitro experiments showed that the extracts of $C$. officinalis and E. purpurea had a positive effect on growth parameters and also antibacterial activity on $\mathrm{Cmm} \mathrm{T} 7$.
Supporting to our result, Goyal and Mathur (2011) also reported that there was an excellent inhibition response of $C$. officinalis extracts against Escherichia coli, Pseudomonas aeruginosa, Enterococcus sp., coagulase-positive Staphylococcus sp., together with coagulase-negative Staphylococcus sp., C. albicans and Candida parapsilosis. In addition to antibacterial activity, antifungal activities of $C$. officinalis extracts have also been investigated (Gazim et al., 2008; Goyal \& Mathur, 2011). One of them was carried out by Mehtab et al. (2017). They concluded the antifungal activity of the $C$. officinalis on A. pori, A. niger and Diplodia, resulting high amount of inhibition. The other experiment was performed by Efstratiou et al. (2012), revealing antifungal activity when compared to Standard antibiotic, Fluconazole. There are different antimicrobial activities response against different kind of microorganisms. This could be variations of microorganisms (Maeda et al., 2008). 


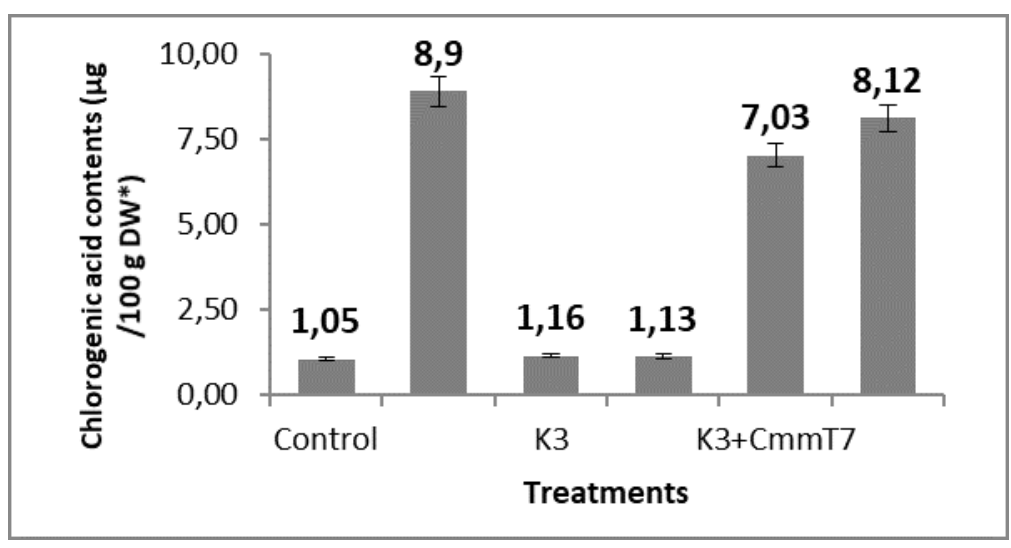

Figure No. 2

Total phenolic compounds contents in tomato seedlings leave (*: DW-dry weight. The values are expressed in mean \pm standard deviation. Different letters above the bars are significant at $p<0.01$ as a result of Duncan's Multiple Range Test)

The antibacterial activity of E. purpurea also showed similar results with $C$. officinalis. Our findings were concordant with Oláh et al. (2017) who showed anti-inflammatory effects of Echinacea purpurea - derived alkylamides on atopic eczema. In addition, Tsai et al. (2012) also examined antioxidant and antimutagenic effects of $E$. purpurea flower extracts, reporting antioxidant and antimutagenic activities in freeze-dried extracts. Another study was also related to phytochemical, antioxidant, antiinflammatory, hypoglycaemic and antiproliferative activities of E. purpurea and E. angustifolia extracts, showing different chemical content and biological effects (Aarland et al., 2017).

Phenolic compounds have been widely investigated in many studies. Lin et al. (2011) reported that cichoric acid was the main and caftaric acid was the second phenolic compounds in dried, $E$. purpurea materials. Moreover, García-Risco et al. (2017) examined Asteraceae (Achillea millefolium and Calendula officinalis) and Lamiaceae (Melissa officinalis and Origanum majorana) extracts in terms of the total content of phenolic compounds. They reported that Asteraceae extracts determined lower content of flavonoids and phenolics than Lamiaceae plant extracts. We identified caffeic, catechin, cinnamic, ferulic, gallic, oxalic, rosmarinic, rutin, salicylic, tannic and vanillic acids in all treatments but chlorogenic acid was found in $\mathrm{Cmm}$ T7-treated leaves (9-fold) when compared to control. There are many studies related to pathogenic bacteria and chlorogenic acid interactions (Baker et al., 2017). One of them was performed by López-Gresa et al. (2011). They supported our results and concluded that a rapid increase in the concentration of chlorogenic acid in tomato plants after infection with the bacterial pathogen Pseudomonas syringae. Moreover, Aksoy et al. (2017) also analysed the effect of Pseudomonas putida on tomato infected by C. michiganensis subsp. michiganensis. They revealed that $P$. putida - treated and $C$. michiganensis subsp. michiganensis - treated plants showed varying amounts in terms of chlorogenic acid, caffeic acid, catechin and rutin phenols. Moreover, they reported a direct relationship between the level of catechin and seedling survivability. Therefore, we could conclude that different phenols might play important roles in different bacterial diseases.

\section{CONCLUSION}

There is no effective pesticide for bacterial canker. Therefore, biological control is an important phenomenon to protect plants also commonly used as alternatives to pesticides. Our results contribute to valuable information related to the effects of phenolic compounds and antibacterial activity of $C$. officinalis and E. purpurea on CmmT7 for the development of natural biopesticides. Further studies are necessary to evaluate which phenolic compounds are responsible for antimicrobial activity in bacterial canker in detail and also the antimicrobial effects of $C$. officinalis and E. purpurea in different bacterial diseases.

\section{ACKNOWLEDGEMENTS}

The authors would like to thank Project Management Office of Ondokuz Mayis University for financial support of the project (PYO.ZRT.1901.14.008) 


\section{REFERENCES}

Aarland RC, Banuelos-Hernandez AE, Fragoso-Serrano M, Del Carmen Sierra-Palacios E, De Leon-Sanchez FD, Perez-Flores LJ, Rivera-Cabrera F, Mendoza-Espinoza JA. 2016. Studies on phytochemical, antioxidant, anti-inflammatory, hypoglycaemic and antiproliferative activities of Echinacea purpurea and Echinacea angustifolia extracts. Pharm Biol 55: 649 - 656. http://doi.org/10.1080/13880209.2016.1265989

Aksoy HM, Kaya Y, Ozturk M, Secgin Z, Onder H, Okumus A. 2017. Pseudomonas putida - induced response in phenolic profile of tomato seedlings (Solanum lycopersicum L.) infected by Clavibacter michiganensis subsp. michiganensis. Biol Control 105: 6 - 12.

https://doi.org/10.1016/j.biocontrol.2016.11.001

Ansari M, Taghavi S, Hamzehzarghani H, Valenzuela M, Siri MI, Osdaghi E. 2019. Multiple introductions of tomato pathogen Clavibacter michiganensi subsp. michiganensis into Iran as revealed by a global-scale phylogeographic analysis. Appl Environ Microbiol 85: 02098-19.

https://doi.org/10.1128/AEM.02098-19

Bahaman AH, Roswanira AW, Azzmer AAH, Khairul BAH, Yilmaz K. 2020. Molecular docking and molecular dynamics simulations studies on $\beta$-glucosidase and xylanase Trichodermaasperellum to predict degradation order of cellulosic components in oil palm leaves for nanocellulose preparation. J Biomol Struct Dyn https://doi.org/10.1080/07391102.2020.1751713

Baker CJ, Mock NM, Aver'yanov AA. 2017. A simplified technique to detect variations of leaf chlorogenic acid levels between and within plants caused by maturation or biological stress. Physiol Mol Plant Pathol 98: 97 - 103. https://doi.org/10.1016/j.pmpp.2017.04.003

Ben-Erik VW, Michael W. 2004. Medicinal Plants of the Worlds. Timber Press, USA.

Chiou SY, Sung JH, Huang PW, Lin SD. 2017. Antioxidant, antidiabetic, and antihypertensive properties of Echinacea purpureaflower extract and caffeic acid derivatives using in vitro models. J Med Food 20: 171 179. https://doi.org/10.1089/jmf.2016.3790

Efstratiou E, Hussain AI, Nigam PS, Moore JE, Ayub MA, Rao JR. 2012. Antimicrobial activity of Calendula officinalis petal extracts against fungi, as well as Gram-negative and Gram-positive clinical pathogens. Complement Ther Clin Pract 18: 173 - 176. https://doi.org/10.1016/j.ctcp.2012.02.003

García-Risco MR, Mouhid L, Salas-Perez L, Lopez-Padilla A, Santoyo S, Jaime L, De Molina AR, Reglero G, Fornari T. 2017. Biological activities of Asteraceae (Achillea millefolium and Calendula officinalis) and Lamiaceae (Melissa officinalis and Origanum majorana) plant extracts. Plant Foods Hum Nutr 72: 96 102. https://doi.org/10.1007/s11130-016-0596-8

Gartemann KH, Kirchner O, Engemanni J, Grafen I, Eichenlaub R, Burger A. 2003. Clavibacter michiganensis subsp. michiganensis: first steps in the understanding of virulence of a Gram-positive phytopathogenic bacterium. J Biotechnol 106: 179 - 191. https://doi.org/10.1016/j.jbiotec.2003.07.011

Gazim ZC, Rezende CM, Fraga SR, Svidzinski TE, Cortez DG. 2008. Anti-fungal activity of the essential oil from Calendula officinalis L. (Asteraceae) growing in Brazil. Braz J Microbiol 39: 61 - 63. http://doi.org/10.1590/S1517-83822008000100015

Gleason ML, Gitaitis RD, Ricker MD. 1993. Recent progress in understanding and controlling bacterial canker of tomato in eastern North America. Plant Dis 77: 1069 - 1076. https://doi.org/10.1094/PD-77-1069

Goyal M, Mathur R. 2011. Antimicrobial effects of Calendula officinalis against human pathogenic microorganisms. J Herb Med 5: 97 - 101.

Khare CP 2011. Encyclopedia of Indian medicinal plants. Springer-Verlag Publisher, Germany.

Jimenez-Medina E, Garcia-Lora A, Paco L, Algarra I, Collado A, Garrido FA. 2006. New extract of the plant Calendula officinalis produces adual in vitro effect: cytotoxic anti-tumor activity and lymphocyte activation. BMC Cancer 5: 119. https://doi.org/10.1186/1471-2407-6-119

Lauk L, Lo Bue AM, Milazzo I, Rapisarda A, Blandino G. 2003. Antibacterial activity of medicinal plant extracts against periodontopathic bacteria. Phytother Res 17: 599 - 604. https://doi.org/10.1002/ptr.1188

Latifian E, Arvas YE, Kaya Y. 2018. Tagetes minuta Bitkisinin Mikro Üretimi Üzerine Farklı BAP ve IAA Konsantrasyonlarının Etkileri. Int J Life Sci Biotech 1: 96 - 104. https://doi.org/10.38001/ijlsb.487354

Lin SD, Sung JM, Chen CL. 2011. Effect of drying and storage conditions on caffeic acid derivatives and total phenolics of Echinacea purpurea grown in Taiwan. Food Chem 125: 226 - 231.

https://doi.org/10.1016/j.foodchem.2010.09.006

López-Gresa MP, Torres C, Campos L, Lison P, Rodrigo I, Belles JM, Conejero V. 2011. Identification of defence 
metabolites in tomato plants infected by the bacterial pathogen Pseudomonas syringae. Environ Exper Bot 74: 216 - 228. https://doi.org/10.1016/j.envexpbot.2011.06.003

Maeda Y, Loughrey A, Earle JAP, Millar BC, Rao JR, Kearns A, Mc Conville O, Goldsmith CE, Rooney PJ, Dooley JSG, Lowery CJ, Snelling WJ, Mcmahon A, Mcdowell D, Moore JE. 2008. Antibacterial activity of honey against community-associated methicillin-resistant Staphyloccusaureus (CA-MRSA). Complement Ther Clin Pract 14: 77 - 82. https://doi.org/10.1016/j.ctcp.2007.11.004

Mehtab R, Misra A, Sharma M, Yadav K, Naik AA, Narayan P, Bhatnagar T. 2017. Characterization of the antifungal activity of waste ornamental flowers (Calendula officinalis and Chrysanthemum) against plant pathogens. Imp J Interdiscip Res 3: 318 - 322.

Muley B, Khadabadi S, Banarase N. 2009. Phytochemical constituents and pharmacological activities of Calendula officinalis Linn (Asteraceae): a review. Trop J Pharm Res 8: 455 - 465.

https://doi.org/10.4314/tjpr.v8i5.48090

Moustaine M, El Kahkahi R, Benbouazza A, Benkirane R, Achbani EH. 2019. Potential of biological treatments for control of bacterial canker of tomato incited by Clavibacter michiganensis spp michiganensis in Morocco. Eurasia J Biosci 13: 1481 - 1488. https://doi.org/10.4314/tjpr.v8i5.48090

Olah A, Szabo-Papp J, Soeberdt M, Knie U, Dahnhardt-Pfeiffer S, Abels C, Biro T. 2017. Echinacea purpureaderived alkylamides exhibit potent anti-inflammatory effects and alleviate clinical symptoms of atopic eczema. J Dermatol Sci 88: 67 - 77. https://doi.org/10.1016/j.jdermsci.2017.05.015

Osdaghi E, Rahimi T, Taghavi SM, Ansari M, Zarei S, Portier P, Briand M, Jacques MA. 2020. Comparative genomics and phylogenetic analyses suggest several novel species within Clavibacter sp. including nonpathogenic tomato-associated strains. Appl Environ Microbiol 86: e02873-19 https://doi.org/10.1128/AEM.02873-19

Tireng Karut Ş, Horuz S, Aysan Y. 2019. Domates Bakteriyel Kanser ve Solgunluk Hastalı̆̆ Etmeni Clavibacter michiganensis subsp. michiganensis' in Tohumda Aranması ve Farklı Tohum Uygulamalarının Hastalık Gelişimi Üzerine Olan Etkisinin Belirlenmesi. J Tekirdag Agric Fac 16: 284 - 290.

https://doi.org/10.33462/jotaf.526167

Tortora GJ, Funke BR, Case CL. 2001. Microbiology: An Introduction. Benjamin Cummings, UK.

Tsai YL, Chiou SY, Chan KC, Sung JM, Lin SD. 2012. Caffeic acid derivatives, total phenols, antioxidant and antimutagenic activities of Echinacea purpurea flower extracts. J Food Sci Technol 46: 169 - 176. https://doi.org/10.1016/j.lwt.2011.09.026

Utkhede R, Koch C. 2004. Biological treatments to control bacterial canker of greenhouse tomatoes. Biol Control 49: 305 - 313. https://doi.org/10.1023/B:BICO.0000025373.69584.08

Valdés RA, Castillo FDH, Cabello JCA, Fuantes YMO, Morales GG, Cantú DJ, Aguilar CN. 2017. Review of antibacterial activity of plant extracts and growth-promoting microorganism (gpm) against phytopathogenic bacterial tomato crop. Eur J Biotechnol Genet Eng 4: 11 - 36.

Xu X, Miller SA, Baysal-Gurel F, Gartemann KH, Eichenlaub R, Rajashekara G. 2010. Bioluminescence imaging of Clavibacter michiganensis subsp. michiganensis infection of tomato seeds and plants. Appl Environ Microbiol 76: 3978 - 3988. https://doi.org/10.1128/AEM.00493-10

Yang SC, Arasu MV, Chun JH, Jang YS, Lee YH, Kim IH, Lee KT, Hong ST, Kim SJ. 2015. Identification and determination of phenolic compounds in rape seed meals (Brassica napus L.). J Agric Chem Environ 4: 14 - 23. https://doi.org/10.4236/jacen.2015.41002 